\title{
Correction: A chemical inhibitor of PPM1D that selectively kills cells overexpressing PPM1D
}

S. Rayter - R. Elliott - J. Travers - M. G. Rowlands - T. B. Richardson - K. Boxall • K. Jones - S. Linardopoulos • P. Workman - W. Aherne - C. J. Lord · A. Ashworth

Published online: 19 May 2020

(c) Springer Nature Limited 2020

Correction to: Oncogene

https://doi.org/10.1038/sj.onc.1210729
Following the publication of this Article, the Authors noted that a p 38 band was omitted from Fig. 3. The corrected Figure is shown below.

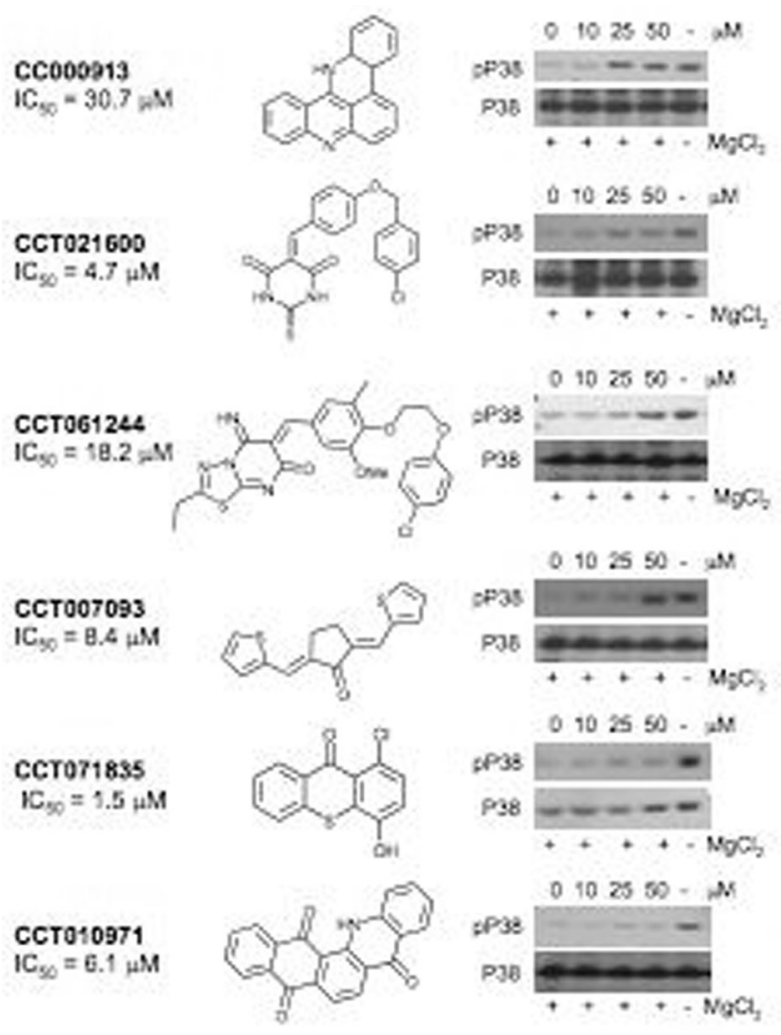

